2020 TheoLogica

An International Journal for Philosophy of Religion and Philosophical Theology

S. I. CONCILIAR TRINITARIANISM

DOI: https://doi.org/10.14428/thl.v4i2.23803

\title{
Is Subordinationism a Heresy?
}

\author{
MARK EDWARDS \\ Oxford University \\ mark.edwards@chch.ox.ac.uk
}

\begin{abstract}
The modern resurgence of orthodoxy in Anglican circles takes as its cardinal tenet the eternal coinherence of three persons in the one Godhead, equal in substance, rank and power. This is assumed to be the doctrine of the Nicene Council of 325, and the putative heresy that denies it is known by the term subordinationism. Although the ample lexicon of Greek heresiology supplies no clear antecedent for this term, the charge of subordinationism is thought to imperil any claim to be teaching in the catholic tradition, even if the teacher is Barth or Rahner. The confidence with which these accusations are levelled, however, seems to be in an inverse ratio to the accuser's knowledge of history, for neither in New Testament scholarship nor at the cutting edge of the modern study of patristics will one find much evidence that subordinationism is even an anomaly, let alone an aberration from the biblical or conciliar norm. It is only in modern theology, not in the writings of empirical historians, that the Gorgon's head of Arius is held up to those who question the strict equality of persons. At the same time, we must not forget that the systematician's reading of Nicaea was until recently also that of the historian. No doubt the reason is partly that until the last half-century every historian was also a confessional theologian; but there is also a certain truth in the older approach so long as some pains are taken to define "subordination".
\end{abstract}

Keywords: Trinity, Heresy, Subordination, Creeds

My purpose in this essay is therefore to ascertain in what sense orthodox writers have rejected, and in what sense they have condoned, the subordination of God the Son to God the Father. According to my taxonomy, subordination will be

(a) ontological when it ascribes to the Son a substance, nature or essence which is inferior to the Father's;

(b) aetiological when it asserts the Son's posteriority in the order of causation;

(c) axiological when it degrades him in rank or status without denying his equality in nature; 
(d) economic when it dates the subservience of the Son to the Father from some point after his origin, most commonly from his voluntary assumption of human nature.

I shall begin by collating the texts that have commonly been cited from the New Testament either in favour of or against the equalisation of the three persons; after reviewing the doctrines of the early church (which of course were not independent of these texts ${ }^{1}$ ) I shall examine the use that was made of them in the Bible and the Fathers by three seminal writers in the English tradition. Milton will represent the Bibliolatrous extreme of Protestant thought, Cudworth the characteristically Anglican tempering of theology by philosophy, and Bull the attempt of an independent mind to perfect the alignment between the Church of England and the early saints whom it claimed for its own.

\section{Biblical Testimonies}

All oecumenical councils profess to be faithful to the scriptures, and even when they invoke patristic authorities, they invoke them as interpreters of scripture, not as independent vessels of revelation. It is not my object here to present my own appraisal of the scriptural evidence, but to offer an inventory of the texts that have been employed in debate throughout the centuries - and thereby to show, as I hope, that we cannot get behind tradition by asking the Bible itself to give us a simple affirmative or negative to the question "Is Christ God?" A detailed review of scholarship would leave no room for discussion of the Fathers and their successors, but it should at least be clear that we need not imitate the scholarship of the last century in tracing subordinationism to Plato (Chadwick 1966, 15-16), together with any other element in ante-Nicene thought that is deemed to fall short of orthodoxy; I shall leave it to Cudworth to put the opposite case, that the Platonists were both better thinkers and better Christians than some accredited doctors of the church.

There is little in the New Testament to suggest that the Son is equal to the Father, and not even an explicit assertion of their coeternity. The Word (not yet called the Son) was with the Father in the beginning (John 1.1)-an expression which takes us no further back than the origin of the world, perhaps no more than four thousand years before the incarnation on a strict construal of biblical chronology. He (or should we say "it"? ${ }^{2}$ ) is said to be theos, but the absence of the

\footnotetext{
${ }^{1}$ Patristic citations can be verified conveniently in relevant volumes of the Library of the AnteNicene Fathers and Library of the Nicene and Post-Nicene Fathers, both edited by Philip Schaff and constantly reprinted by Eerdmans.

2 Against the view that John was proclaiming a "pre-existent Jesus" see Dunn (1989, 213-250). Contrast L. Hurtado $(2005,118-121)$.
} 
definite article-used in the previous clause when the subject is God the Fatherpermits, or may even embolden, us to take this usage of theos as predicative rather than denominative. The New English Bible captures this well in its rendering "what God was the word was", and the closest parallel in the Bible itself is Exodus 7.1, "I shall make thee theos to Pharaoh", where the implication is evidently that Moses will be all that Pharaoh knows of God, not that he will be God in substance. There is no other passage in which the word theos is incontrovertibly applied to the Son: even Thomas's exclamation "My Lord and my God" (John 20.28) is understood by a minority of readers as a prayer of thanksgiving rather than an apostrophe to the resurrected Jesus. ${ }^{3}$ Again, it is not uncommon to take "God over all, blessed for ever" at Romans 9.5 as an elliptical benediction of the Father, rather than as an honorific phrase in apposition to the name Christ. Most scholars prefer the variant "He was manifest in flesh" to "God was manifest in flesh" at 1Timothy 3.16; opinion is more divided as to whether Acts 20.28 should be understood to say that God shed "his own blood" for our salvation or that he shed "the blood of his own. It is not clear whether Titus 2.13 acclaims one being, our God and Saviour Jesus Christ, or whether "our God" is its first subject and "our Saviour Christ" the second. Nor is it certain whether the Son or the Father is the antecedent of "He is the one true God" at 1 John 5.20 (cf. Westcott 1892, 186-187); there is of course no doubt that it is the Son who confers this title upon the Father at John 17.3.

The Son declares throughout the Gospel of John that he performs the works of his Father (10.37), that what he sees the Father doing he himself does likewise (5.19), and that therefore he has a testimony from the Father which is stronger than that of any human witness (5.32-36). There is no corresponding testimony of the Son to the Father, nor any hint that the Father imitates the works of the Son. If the asseveration "I and the Father are one" (John 10.30) were a claim to be of one substance with the Father, why should not the same inference be drawn from Paul's saying that "he that is joined to the Lord is one spirit" (1 Corinthians 6.17)? ${ }^{4}$ On the other hand, John 14.28, "the Father is greater than I", is an unmistakable admission of inferiority (cf. Barrett 1974). Tertullian quotes it in triumph to prove that the Son is not identical with the Father (Against Praxeas 9.2); Athanasius, taking "greater" to signify "causally prior", embraces it as a scriptural proof that the Son is of one nature with the Father, as we do not engage in quantitative comparisons between beings of different natures (Against the Arians 1.58). Gregory Nazianzen, while admitting that the Father is the cause of the Son, maintains that it is not this aetiological dependence but the Son's

\footnotetext{
${ }^{3}$ For this gloss in Theodore of Mopsuestia's Commentary on John, see Behr $(2011,372)$.

${ }^{4}$ Cf. Origen, Against Celsus 2.9.
} 
voluntary assumption of a creaturely state that justifies the term "greater": the Son is inferior insofar as he wills to be sent and to serve. ${ }^{5}$

Thus there are scriptural texts that can be construed as ascribing to divinity to Christ, and others that represent him as the Father's willing servant in his ministry on earth. His economic subordination is the heart of the gospel; of ontological, aetiological or axiological subordination nothing is said and little can be deduced, because it did not seem to the prophets and apostles that such metaphysical questions have any bearing on our salvation. Those exegetes whom we now know as the Church Fathers find it necessary to treat of them, and in the next two sections we shall see how it became as much a note of catholicity to affirm the causal priority of the Father as to deny the Son's inferiority to him either in essence or in rank.

\section{The Church before Nicaea}

Once it is understood that the true distinction is not between the manhood and the Godhead but between the Godhead incarnate and the Godhead in itself, the objection that Gregory's "partitive exegesis" threatens the unity of Christ is no longer valid; in fact it preserves the narrative form of the Nicene Creed, which commemorates not the union of two antecedent natures but the miracle of God's becoming man. Nevertheless, this theory eluded the church before Nicaea, which tends to posit not the nativity but the incarnation as the great caesura in the existence of the Second Person. Emergence from the Father (assumed to be a transition, not an eternal generation) establishes not only his distinctness but his finitude in contrast to the infinite transcendence of the one who is truly God. Justin explains that God the Father creates, administers and redeems the world through his Son because he cannot enter it himself, whereas the Son is of a nature that can admit of limitation (Dialogue with Trypho 60): his apparitions to Abraham, where he takes on the angelic role without forfeiting his divinity, reveal his subaltern character as clearly as his acceptance of the Cross (Trypho 55-56).

Tertullian, who affirms not only that the Son is divine but that he and the Father are of one substance, appears to think it self-evidently blasphemous to suppose that the Father could have undergone the crucifixion (Against Praxeas 1.1 etc.). While neither position lends itself to precise formulation, that of Justin tends to an ontological, and that of Tertullian to an axiological subordination of the Son to the Father. His task, like that of all writers in the catholic tradition of Christian thought, is to account for the paradoxical worship of a second being in a faith that proclaimed the unity of God. The monarchian or Sabellian way of declaring the Son to be merely the Father's human incognito is closed to him; so is that of

\footnotetext{
${ }^{5}$ Gregory Nazizanzen, Theological Orations 29.18 and 30.7.
} 
the Gnostics, Valentinian and Marcionites, who each in their own manner set one deity over creation and one over redemption, pronouncing the former in some degree inimical to the second. If the church found itself honouring two subjects, both called God, it could sustain its monotheism by holding one to be God in the true sense and the other only in a derived or less perfect sense.

Much more representative of his time, and thus more odious to the champions of orthodoxy in the fourth century, was Origen, the first critic to draw the distinction explained above, between theos with the definite article and theos in its predicative application. Yet Origen in his own time was suspected of preaching two gods rather than one because he affirmed the second person to be coeternal with the first, a position held to be irreconcilable with the naming of one as Son and one as Father. ${ }^{6}$ Inasmuch as it awards a higher mode of being to the Father, his is not merely an aetiological but an ontological subordination; axiological subordination is clearly attested when he stipulates in his treatise On Prayer that the prayer of adoration should be addressed to the Father alone (15.1). Whether he is explaining or correcting the prevalent custom we cannot say, but he is evidently speaking in his own vocabulary when he adds that the Son differs both in hypokeimenon and in ousia from the Father. The first term should be rendered as "subject" if it refers to the pre-incarnate Son; if it has the sense of "substrate", i.e. matter, it implies that the Son is not exempt in heaven from the economic subservience which he accepted when he took flesh. Since he affirms elsewhere that the Son and the Father share a nature, the term ousia is best understood in the sense of "concrete being" rather than "essence", in which case subordination in any of the four modes specified above may be implied.

He continued to describe the birth of the Son as an emanation-no longer temporal, as in the apologists, but eternal-and for this he was denounced as a Valentinian. Later generations took offence not at these passages but at his likening of the Son to a finite image of the immeasurable (First Principles 1.2.8), and at his statement that the Father presides over all things in creation, the Son only over those endowed with reason. The first simile implies that he lacks something of the Father's nature, the second that he lacks something of his power. But what does he understand by the biblical dictum that the Son is the Father's image? Paul at Colossians 1.15 is most probably speaking of the incarnate Christ as the image of the invisible God, whereas Origen adds the adjective "invisible" to "image" also, thereby intimating that the Son is the Father's image even within the Trinity. And yet he goes on to speak of this same image as having shown his obedience even to the Cross. We cannot be sure, then, whether the Son is inferior to the Father as Second Person of the Trinity or only

\footnotetext{
${ }^{6}$ See Pamphilus, Apology for Origen 94-108, in the edition of G. Rowekamp (2005). Sonship is reconciled with coeternity when we posit an "eternal generation", but this phrase perhaps originates with Plotinus, Enneads 5.1.6.39 and 6.8.20.27.
} 
as Christ enfleshed. The question that was of such consequence after Nicaea - is the subordination economic or ontological? - does not seem to have exercised the most tenacious theologian of the third century.

\section{Nicaea and after}

Arius broke with Origen and the apologists by denying that the Son had come forth from the Father, thereby weakening the analogy with human sonship. He may have purported to strengthen it by declaring that "before he was begotten or created he was not" - that is, he existed neither within the Father nor as a discrete hypostasis; the church after Origen, however, was not prepared to set limits to the longevity of the Son, and still less to admit that, like the world, he was "out of nothing", even if Arius urged that no other formula would preserve the integrity of the Father's substance. Therefore both "he was not" and "out of nothing" are anathematised on the Nicene Creed of 325; the assertion that the Son is "true God from true God" implies that the Father is the subject of John 17.3 and the Son of I John 5.20. The adjective homoousios, together with the assertion that the Son is "from the ousia of the Father" preclude ontological subordination; neither in its original form, however, nor in the augmented version of 381 which is now used more familiar, does the creed state that the two persons are equal in rank, and the aetiological priority of the Father is asserted in all three times.

Athanasius, whose championship of the Creed also determined its interpretation for centuries, admits the aetiological subordination of the Son to the Father in the exegesis of John 14.28 which is quoted above. Axiological subordination is precluded by his rejoinder, to those who urge that the Son is an image of the Father, that the image of the Emperor is worthy of the same honour as the Emperor himself (Against the Arians 3.6). Although this biblical metaphor, if not restricted to the earthly ministry, implies ontological subordination, Athanasius grants it here for the sake of his argument; elsewhere he upholds the formula "from the ousia" and the adjective homoousios with a zeal that leaves us in no doubt of his hostility to ontological subordination. It has been remarked none the less that he employs the term homoousios always of the Son in relation to the Father, never of the Father in relation to the Son. While isotês (equality) is a salient term in his vocabulary, it never denotes more than possession of the same nature. After all, the Son owes his homoousiotês to his being from the ousia of the Father: the act of generation is not reversible, and as Apollinarius was later to inform Basil, the Trinity is one God because the Son and the Holy Spirit owe their being, and the nature of that being, to the Father, with whom they are one as a race or tribe is one with its progenitor (Basil, Letters 361-164).

As an argument against Arius Athanasius urges that the church offers prayers to Christ, and so he cannot be less than God (Against the Arians 3.12). His 
argument makes no allusion to any such curtailment of these orisons as Origen prescribes in his treatise On Prayer. The question is not for him only a metaphysical one, for if Christ were not God in the full sense, he alleges, we could not become gods, as the gospel promises, by participation in his nature (Against the Arians 2.69-700. This reasoning is questionable, for the sense in which the saints are to be gods is not the sense in which the Father is God, and hence it might be possible for one who is less than the Father to impart such divinity is we can receive. Cappadocians too enjoin that equal honours be paid to the Son is the image of the Father-so equal that whenever they assert that the eternal Son is the "image" of the Father, they add a caveat against taking "image" in its usual acceptation. Thus Basil urges at On the Holy Spirit 45 that the Son possesses by nature the likeness to his Original that a statue possesses only by imitation, while Gregory Nazianzen, at Oration 30.20, contrasts the common statue, which is a "motionless imitation of the immobile", with the Son who is the "living reproduction of Him who has life". ${ }^{7}$

Yet Gregory of Nyssa is wholly at one with Athanasius in holding that the only ground of difference within the Godhead, the causal primacy of the Father, is also the precondition of its unity. ${ }^{8}$ If there were no such bond they would be mere instantiations of a common species, and no reason could be given why there might not be two or four. It was in this respect that homoousian differed from homoiousian doctrine. ${ }^{9}$ The substitution of the fictitious watchword homoiousios (cf. Barnes 2006) for the phrase in use, homoios kat' ousian, has given rise to the erroneous notion that its proponents taught a similarity, rather than an identity, of nature. The formula was designed, however, not to diminish Christ's likeness to the Father but to intimate that, however like, the Father and the Son were not one subject, as a heretic might infer from the prefix homo-. If we mean by ousia the ensemble of attributes which, according to some logicians, constitutes a species, the two were certainly understood to be members of the same species and hence to be "like" inasmuch as they had the same essential attributes. The Nicene party resists this theory because it obscures the derivation of the Son and Spirit from the Father; their most intransigent adversaries, known as Anomoeans because they admitted no likeness of nature between the persons, agreed with

7 The Cappadocians will have been aware of Aristotle's observation, on the first page of the Categories, that a statue differs from its prototype in the definition of its being (logos tês ousias).

8 See further Zizioulas (1985). On the licence with which he interprets both western and Cappadocian traditions, see Ludlow (2007, 52-68).

9 See further Edwards (2009, 122-124), quoting Marius Victorinus, Against the Arians 1.29 (Locher 1976, 63): "You say that both Father and Son are homoiousios. Which is like to which? The Son to the Father, in dignity and dignity of nomenclature? But so indeed the Father to the Son; for all [relatives] are in relation to something." 
them in regarding the Homoiousian, rather than the Homoousian, position, as the one that implies complete equality. ${ }^{10}$

Augustine's work On the Trinity opposed both the Anomoeans and the Homoians who confessed likeness but with no mention of ousia. He has been commended (in the west) for ridding theology of the Platonic malaise of subordinationism, chiefly on the grounds, that by acknowledging the Son's role in the production of the Spirit and the Spirit's role in cementing the love of the Father and the Son, ${ }^{11}$ he has grounded the unity of the Godhead in the mutual relations of the three persons rather than in the primacy of the Father. Unfriendly critics object that in his wake the western tradition has tended to think of the Godhead as an abstraction which is logically anterior to the persons (cf. Zizioulas $1985,40)$. He himself is clearly not chargeable with this error, for he stipulates that divinity, the essence of God, is nothing other than God (On the Trinity 5.11.12). He also implies that aetiological precedence entails economic primacy, repeatedly observing that the Son, not the Father, is the one who is sent, and that the Father, not the Son, is the one revealed (cf. Gioia 2008, 78-83). The model of God as species which he rejects is the homoiousian one which the Cappadocians too had perceived (if not so clearly as he did) to be in need of correction (On the Trinity 5.11.12). Thus the aetiological priority of the Father is axiomatic to his doctrine of the Trinity; on the other hand, he offers no purchase to either the axiological or the ontological modes of subordination, for it is only in the flesh that the Son is "sent" to "reveal" the Father. The epiphanies to the patriarchs, which Justin and others attributed to the Son alone as the image of the Father, are explained by the mature Augustine either as angelophanies or as apparitions of all three persons together, since no one of them is more disposed by nature than the others to be seen by the human eye (On the Trinity 2.16.27-2.18.33; 3.11.7883).

\section{The Protestant Revolution}

An admirer of Augustine opined that his Trinitarian doctrine was in substance that of Calvin, though only the latter was bold enough to declare that each of the persons is autotheos, equally divine. ${ }^{12}$ For those who embraced the Protestant Reformation, it entailed above all a renunciation of Papal sovereignty, together with any article of teaching, whether ethical, liturgical or doctrinal, which was supported only by the authority of the Papal church and not by the testimony of

10 Thus the "Anomoean" Eunomius, Liber Apologeticus 26.23-24, in Vaggione (1983, 70): "neither homoousios nor homoiousios, seeing that the former connotes generation and division of the substance, the latter equality" (my translation).

11 See On the Trinity 8.10.14 etc., with Chadwick $(1966,16)$.

12 Warfield (1956, 272-284). For Calvin I have used Beveridge (1989). 
scripture. Of course there was not universal agreement as to what was taught in scripture, nor indeed as to what should be taught as scripture, for there was obviously some force in the Papal argument that neither the Old Testament nor the New had drawn up a canon of its own contents. The decision of Calvin and of every church that shows his influence was to adopt the Jewish canon of the Old Testament (thus excising all that was extant only in Greek) and all the Greek texts that were customarily held to comprise the New Testament, notwithstanding Luther's strictures on Hebrews, James and Revelation. The Lutheran churches in fact concurred, as did the 39 Articles of the Church of England. Whereas Calvin, however, held that a genuine work of inspiration commends itself to those who possess the light from above, the English tradition seems to have given more credit to the argument that there cannot be a canon without a church. It was therefore enshrined in English law that, while scripture teaches all things necessary to salvation, heresy is defined not only by scripture but by the teaching of the first four oecumenical councils. The apparent contradiction is mitigated by the principle that the Fathers have no independent authority, but only as interpreters of the texts which they themselves had pronounced to be normative (cf. Quantin 2009). It was indeed the Fathers who formed the court, although the law might speak of councils, not only because exegesis was the province of individuals, but because conciliar dogmas, until interpreted by these individuals, were almost as ambiguous as the scriptures. None of the first four councils, after all, decrees that the Holy Spirit is consubstantial with the other persons of the Trinity, or even that he is divine.

The united suffrage of the four doctors- Ambrose, Jerome, Augustine and Gregory the Great - was sufficient for Rome, if less so for Canterbury; but in fact both Rome and Canterbury were willing to receive their doctrines in the more epigrammatic words of a Creed that was ascribed to Athanasius himself (cf. Kelly 1964). While it lacks a Greek prototype and does not appear in any eastern liturgies, it is clearly the work of a gifted hymnodist and metaphysician who was able to say in a series of euphonious antitheses what the creeds of 325 and 381 had failed to enunciate: that while none of the three persons is another person, each is wholly identical with the one being who is God. "The Father is God, the Son is God and the Spirit is God; and yet there are not three gods but one God" and so on without division of substance or confusion of persons. Calvin, in a famous wrangle, doubted whether anyone could be saved if their lot depended on a perfect recital of this formulary (cf. McNeill 1967, 141-142; Barth 1961, 417); nevertheless, it plainly informs his own argument that the name Jahweh in the Old Testament frequently represents the Son (Institutes 1.13.13, citing Joel 2.32 and Proverbs 10.18). He does not contend that the Son and the Father are one in person, only that the name which signifies God is applied univocally to both. Since it was he who authorised the burning of Michael Servetus, Calvin was fully 
aware that those who read scripture without a guide would not always arrive at any notion of the Trinity; for him the Nicene Creed was only one of many documents from antiquity that had failed to encapsulate all the prescriptive articles of belief.

\section{John Milton (1608-1674)}

Calvinists in England were always puritans, but not all puritans were Calvinists. The poet John Milton, also a keen logician and a formidable student of ancient languages, could find no predestination of individuals in his Bible, ${ }^{13}$ and was equally loth to believe that it said anything of Christ which contradicted its clear and recurrent testimony to the unity of God. Why should we or the Holy Spirit compromise the natural sense of this term with respect to God when we would not compromise the natural sense of truth or immortality, omnipresence or omniscience? Sonship is certainly ascribed to Jesus, but not an eternal one: if he were Son by nature, the natural sense of the word would imply that he cannot share the eternity of the Father, for generation is always the bringing into existence of that which did not previously exist. (p. 211). Nor can the Son be of one essence with the Father, for difference in number logically necessitates difference in essence. This principle, formulated in Milton's treatise on logic, ${ }^{14}$ implies that he understood the term essence only in the Aristotelian sense of prime ousia, the concrete individual. If the Son and the Father were coessential, which would be Father and which would be Son? If an eternal being can be begotten, why should the Father not have his own Father (p. 264)? Scripture affords many instances of sonship by adoption, for the elect are sons of God in no other sense (pp. 206-208). The passages in which he implies that what is done to the saints is done to him are undeniably metonymic, and therefore teach us how to read texts in which it might seem that the Son is called Jahweh: while he does indeed receive that name by courtesy from time to time, the literal teaching of scripture at Exodus 23.21 is that he is not Jahweh but Jahweh is in him (p. 257). Honorific metonymy will also explain the Psalmist's acclamation "Thy throne, $\mathrm{O}$ God, is for ever and ever"; 15 the author to the Hebrews, in applying this verse to the Son, builds the rest of his argument on the premise that the Father alone is, in the proper sense, God (pp. 240-241).

Milton's subordinationism is clearly ontological, and purports to be grounded in a consistent reading of the scriptures. It may be that, against his will, he has illustrated the impossibility of such a consistent reading. It is natural that a son

\footnotetext{
${ }^{13}$ On Christian Doctrine 1.3, in Milton (1973, 153-167); see also Kelley's introduction to this volume (74-86).

14 Art of Logic 1.7 in Milton (1982, 233).

${ }_{15}$ Hebrews 1.8, citing Psalm 45.6.
} 
should be chronologically posterior to his father, but only if his father begets him in the course of nature. Once we deny a natural begetting, the consequences of a metaphorical usage of the term are less than plain. The plain and natural sense of "thy throne, O God, is for ever and ever" is that the addressee is God; most probably the Psalm from which the verse is taken employed the name God honorifically than literally, but if we are bound to honour the intention of the Psalmist, we should resist any Christological application of his conceits. A similar paradox arises in Paradise Lost, where God declares to the angels "This day I have begot/My only Son". ${ }^{16}$ These words from Psalm 2.7 were in the Hebrew text no more than a salutation of the king at his enthronement; in Milton they gave the same force, as the Son is the creator of the angels and is therefore already begotten in the plain and natural sense. Thus the poet exposes the polysemic character of the biblical language which in his prose he treats as though it were univocal; not does he avoid heresy according to the canons of theology after Nicaea, which asserted that the anointing of the Son by the Holy Spirit was coeval with his generation, and consequently eternal. ${ }^{17}$

In Paradise Lost the humiliation of the Son on earth is freely chosen, but not, it appears, from the beginning of his existence. Opposed as Milton was to Calvin's doctrine of individual predestination, he represents the acceptance of the Cross as a remedial measure once the the fall of Adam is known to be inevitable: ${ }^{18}$ the Son who is inferior to the Father in rank and essence voluntarily undergoes an economic subordination. Allowance, of course, must be made for the inevitable constraints of epic poetry, which is obliged to translate the timeless into the temporal and the ineffable into concrete symbolism. Allowance must be made again for a tendency to Latinate constructions which leads Milton to say that the devil feared no created thing except "God and his Son", ${ }^{19}$ which if the literal sense were pressed would make the Father himself a creature. But was it only metrical exigency that produced the expression "filial Godhead"?20 This ought to mean "filial aspect of the one Godhead", since the notion of a second Godhead contravenes the normal use of the term, whether one is a catholic for whom it denotes the Trinity or a Unitarian for whom the sole Godhead is the Father. Again, Milton is all too clearly aware of his own temerity when he suggests that

16 Paradise Lost 5. 603-605: “This day I have begot whom I declare/My only Son, and on this holy hill/Him have anointed whom ye now behold.

17 See Gregory of Nyssa, On the Holy Spirit against the Macedonians.

18 Paradise Lost III.227-265. It is only then, as at Philippians 2.10-12, that the Father commands "Adore the Son, and honour him as me" (III.342).

19 Paradise Lost II, 678-679: "God and his Son except,/Created thing nought valued he nor shunned".

20 Paradise Lost VI. 719-721: “[H]e all his Father full express'd/Ineffably into his face received,/And thus the filial Godhead answering spake."Cf. Colossians 2.9: "in Christ dwelleth all the fulness of the Godhead bodily". 
light may not be so much the "firstborn of heaven" as a coeternal beam of the Eternal. ${ }^{21}$ He does not identify it with the Son, but he does allow here that one attribute of the Father might be shared with another subject-or maybe not another, for, as the poet reminds himself and his readers, "God is light".

Critics have spoken of latent Arianism in Paradise Lost (cf. Bauman 1987; Nuttall 1998); perhaps it would be truer to say that Milton as a poet found it difficult to sustain the Arianism that he formulates so rigorously in prose. Perhaps, because the poet is bound by more conventions than the writer of prose, he cannot be equally intrepid in speculation; perhaps the imagination of a Christian recoils from any diminution of the Saviour's glory, whatever the intellect may propound. It may not be irrelevant to note that while the Church of England's liturgy is as reticent as the New Testament in addressing prayers to Christ, there has been no want of such devotions in the writings of its poets and hymnodists

\section{Anglican Speculations}

In an enterprising study of Milton's theology (Hunter 1954), his fellowCantabrigian Ralph Cudworth (1617-1688) is adduced as an example of what could be tolerated in Protestant divinity of this era. Cudworth, an Anglican cleric, was in this and other respects the perfect antitype to Milton. For him, as for all the latitudinarians whom we know as the Cambridge Platonists, the assassins of faith are Hobbes and Calvin, both of whom impeach the justice of God but their fatalism while the former's materialism robs God of that which makes him God. He chooses philosophy rather than theology as his battleground in his Intellectual System of the Universe, ${ }^{22}$ where the atomists - whom he pronounces to be atheists to a man, Pythagoreans included- are evidently prototypes of Hobbes. The dominant and more genuine strain in Greek thought, represented both in popular myth and in its Orphic redactions (II, 73-101), proclaims that God is one and that gods are many. In the loftiest of the pagan philosophies, that of Plato, the lesser beings owe their divinity to their participation in one first principle. His pupil Aristotle endorsed his principles that God is one and that no God can be inert (II, 518-524), and hence was rightly understood by the Neoplatonists to have followed him in endowing the world with a soul (II, 313).

While atheists cannot maintain the eternity of the world (I, 301-308), the true theist, like Plato, holds it to be a deliberate creation at some point in the past (I, 493-497). We cannot lay at Plato's door the ditheism of his late admirer Plutarch,

${ }^{21}$ Paradise Lost III.1-3: “Hail, holy light, offspring of Heav'n first-born,/Or of th' Eternal coeternal beam, /May I express thee unblamed? since God is light", etc. Cf Genesis 1.3, John 8.12, 1 John 1.5 .

${ }^{22}$ Citations are from Cudworth (1820), but the original date of publication is 1678 . 
who is consciously original in setting an evil soul in matter against a benign world-soul (I, 440-456). The Platonists who followed him were true to their founder in admitting no independent principle of evil; and yet they were not so much ditheists as tritheists inasmuch as they added the world-perhaps more properly the world-soul - to the principles of unity and demiurgic action (III, 43). Both this figment and their assertion of three gods or three natures betray an adulteration or depravation of the true doctrine (III, 44, 46, 50). At the same time, Cudworth argues, the conjunction of the three deities is so intimate that they are properly one divine ensemble, even if Neoplatonists could not admit their consubstantiality (III, 115-124). Their notions of gradation and dependence within the triad have been contrasted with the Christian doctrine of a coequal Trinity; all Christians before Nicaea, however, held that the persons differed in rank (III, 131), and even for Athanasius homoousiotês connotes not an absolute oneness in essence (that is Sabellianism, and a heresy), but equality in the sense of possessing "one common or general essence of the Godhead" (p. 166). This is compatible with, and indeed entails, the Son's dependence on the Father (III, 154); the Platonists shunned the term homoousios only because it seemed to them to betoken "three independent and co-ordinate individuals" - an error which beguiled even some of the Fathers (III, 148). Thus the gradation of persons is aetiological in both systems, and there is no such disparity between the Platonic and the Christian Trinity as is supposed by "some late writers" who mistake the Athanasian Creed for a primitive confession (III, 183).

While it was Platonism that revealed to Cudworth the path between Rome and heresy, the Lord Bishop of St David's came to almost the same opinion through an assiduous perusal of the Fathers. George Bull (1634-1710) defended good works and free will against self-styled pupils of Augustine, but the work of his life to prove that the Church of England, not the Church of Rome, had preserved the legacy of the Fathers. ${ }^{23}$ His Roman interlocutor, Dionysius Petavius, (15831652) maintained that by admitting the authority of four oecumenical councils, the English divines had confessed that a teaching might be prescriptive even if it were not primitive, and hence they must confess the necessity of some institution to oversee the unfolding of the true doctrine. Bull's response is to forestall the inference by demonstrating the falsehood of the premise: in his submission, as in its own, the Nicene Council affirmed no other Creed than that which had been passed down from apostolic times in every quarter of the Christian world. While it might seem, for example, that to teach the Son's coeternity with the Father was to contradict Psalm 2.7 "thou art my son, this day gave I begotten thee" the tradition before Nicaea had already observed that the first clause says "Thou art", not "Thou hast become", thus intimating that, whatever the begetting may be,

${ }^{23}$ Citations are Bull (1846). 
the Sonship is eternal (p. 545). Begetting is thus construed as enthronement, in keeping with the intent of the Psalmist, as we observed with respect to Milton. And as we also observed, the apology is incomplete, for post-Nicene orthodoxy taught that the Son's anointing is as eternal as his generation; Bull's aim, however, is to vindicate the consistency of patristic teaching, not to answer every objection that an Arian might raise against the Creed.

Neither the divinity nor the consubstantiality of the Son are admitted by Bull to be innovations. It is all the more remarkable then, and was prejudicial to his own reputation for orthodoxy, that he should not hold the equality of the Son and the Father to be a catholic doctrine originating with the apostles. His argument, in a sequel to his Defence of the Nicene Faith, is that the subordination of the Son to the Father was not only the common tenet of the church before Nicaea, but is presupposed by the Nicene Creed itself and by its most esteemed interpreters in the following century. He maintains in all three theses: that the Creed ratified the antecedent doctrine of subordination and was generally understood to do so (p. 686); that the doctrine was asserted of the Son as Second Person of the Trinity and not only as Christ incarnate (p. 704); and that the salutary consequence of the doctrine is to confirm all the divine attributes of the Son without depriving the Father of his pre-eminence as the one true God ( $p$. 767). The first two theses required to produce testimonies not known from theologians before Nicaea ( as in the Defence) but from Athanasius, Nazianzen. Cyril and Augustine, the recognised arbiters of the Council's meaning; at the same time, the most cogent proofs from scripture are furnished by Origen, of whose orthodoxy Bull entertains no doubt (pp. 716-719; 741-756). His adversaries grant it when, instead of decrying Origen's designation of the Father as autotheos, they pretend that he applies this epithet also to the Son (pp. 701702). That councils purporting to be oecumenical, and theologians echoing these councils, have maintained the equality of the Son and the Father Bull does not wish to dispute; on the contrary, this is evidence of the incapacity of the Roman church to preserve sound teachings. The claim of Petavius, that every council improves and corrects the decrees of its predecessor, is clearly belied by the dissensions of the schoolmen, who present such a sorry contrast to the unanimity of the ancient church.

Working from the Fathers, therefore, Bull comes to the same conclusion as Calvin, who accepts no rule but scripture, as Cudworth in his search for an alliance between the gospel and philosophy, and as Milton the epic poet in contrast to Milton the theologian. He injured his own good name by his use of the term subordination, which he might have eschewed in good faith; his learned proof that not every subordinationist is an Arian may have tempted a younger Anglican, Samuel Clarke into opinions that were thought to savour of this heresy (Clarke 1712). The second-hand quotations from the Fathers which acquitted 
Clarke could not help the Socinians, ${ }^{24}$ who denied the existence of any Second Person other than the incarnate. The English law of blasphemy which pronounces this a crime is now a dead letter; denial of the Trinity, on the other hand, was long ago removed from the statute, ${ }^{25}$ perhaps because Bull had exposed the difficulty of ascertaining what it was lawful to deny.

\section{Concluding remarks}

Anyone who compares the opening section of this paper with those that follow may be surprised that the equality of the Son and the Father became an all but universal dogma despite the silence, or some would say the explicit resistance, of the scriptures. The texts that were thought to attribute divinity to the Son are dubious, and not every use of theos betokened parity with the Father; on the other hand, no syntactic ambiguity occludes his own saying "the Father is greater than I" (John 14.28). The Nicene Creed none the less denies the ontological primacy of the Father; Athanasius, the Cappadocians and Augustine (in contrast to Origen) deny even his axiological primacy. The Conciliar tradition remains more reticent: the redaction of the Nicene Creed in 381 does not explicitly state that the persons are equal in rank, and makes the Father alone the source of the Spirit without affirming that the Spirit is also God (cf. Bindley 1906, 69-92; Smith 2019, 26-27). The tenets that all three persons are God and that all are one God, are enunciated clearly in the Athanasian Creed, a Latin document, which governs the exegesis not only of Calvin (who avowedly put on Augustinian spectacles to read Paul) but of the Platonizing Cudworth and of Bishop Bull, who sets no ancient master above the rest. Even the indomitable Milton cannot sustain in his published epic the sceptical thoughts that he whispered in Latin: we surmised above that the cause of his inconsistency was the popular adoration of Christ, which had been a source of power to Athanasius. What after all, says the common sense of the churches, is the meaning of the name Christian if Christ comes second to some other object of worship?

Some ask why we need a doctrine of the Trinity if the New Testament is not a theological tract but a manual of life, with Christ at its centre. Athanasius would reply that without a true understanding of the Son's oneness with the Father, we cannot unseal the charter that binds creation to redemption, we cannot decide the indicatives of the Old Testament which underlie the imperatives of the New. And yet it is far from obvious that an indicative which excludes subordination is the best warrant for imperatives which are grounded in the belief that the Son gave up his life at the bidding of the Father and was raised up by the Father for our salvation. What do we profit by being told that the Son who obeyed the will

\footnotetext{
${ }^{24}$ Wiles (1994) is often speaking of Socinians rather than true Arians.

${ }^{25}$ In the $53^{\text {rd }}$ year of George III, i.e. 1812. Cf. Bonner and Read $(1934,22)$.
} 
of the Father even to the Cross is so far from being his natural servant that it might logically have been the Father himself who endured this death? The modern aphorism that the immanent Trinity is the economic Trinity reaffirms the principle of Luther and Schleiermacher (which seems also to have been that of Athanasius) that what we know of God is what God reveals and that he reveals it for our sake.

On this presupposition Karl Rahner argues that the Son within the Trinity is eternally predisposed to be the image of the Father, which is to say that he is (as Justin averred) the more knowable, even if we add against Justin that he is so by his own volition, not by nature. ${ }^{26}$ In one of his essays Rahner demonstrates that the Father is the typical, if not the only referent of the noun theos in the New Testament (cf. Rahner 1961, 79-148), ${ }^{27}$ and his thesis will also commend itself to those who hold that the proper subject of the Johannine prologue is not so much eternal Sonship as perennial revelation (cf. Ashton 1998, 5-35). Karl Barth, who has said with even greater force that we know the Trinity only through the incarnation, argues that the purpose of God was to elect us to fellowship with him, and that since we are elected through Christ in his death his subordination to this decree is not a supervenient but an eternal corollary of his sonship (cf. Barth 1956, 52-54, 104). In short, he has been eternally the one who obeys the Father, albeit not in any sense that precludes the co-operation of his own will.

Since neither of these theories asserts the Son's inferiority to the Father in power or in nature, neither can be said to teach the doctrine for which Arius was condemned, or even that which is implied by certain texts on Origen. Before we tax Barth with novelty, let alone heresy, we should note that in Irenaeus also election precedes creation (Against Heresies 3.22). At the same time we may feel that both invite Eusebius' criticism of Arius by making too much of that which the Bible has chosen to leave unsaid. ${ }^{28}$ Certainly we should hesitate to assert that God in himself is other than that which he has revealed himself to be; on the other hand, to assert that he must be exactly as he reveals himself is to abridge his freedom and exaggerate the human capacity for understanding. If God is indeed ineffable, as all champions of the Nicene Creed asseverate, we must deal warily even with the cataphatic, or affirmative, testimonies of scripture; the virtue of the apophatic way which complements this in Christian thought is not that it yields a truer set of propositions, but that it warns us not to imagine that theology can annihilate the gap between the revealed and the unrevealed.

\footnotetext{
${ }^{26}$ See Rahner (1967, esp. 78-88) with Wong (1984).

27 "Theos in the New Testament", in Theological Investigations I (London: Darton, Longman and Todd 1961), 79-148.

${ }^{28}$ Letter of Eusebius to Caesarea, in Theodoret, Church History 1.12,15.
} 


\section{Bibliography}

Ashton, John. 1998. Studying John: Approaches to the Fourth Gospel. Oxford: Clarendon Press. https://doi.org/10.1093/acprof:oso/9780198269793.001.0001.

Barnes, Timothy. 2007. "A Note on the Term Homoiousios." Zeitschrift für Antikes Christentum 10: 276-285. https://doi.org/10.1515/ZAC.2006.020.

Barrett, C. K. 1974. "'The Father is greater than I' (John 14.28): Subordinationist Christology in the New Testament." In Neues Testament und Kirch. Rudolf Schnackenburg am 60. Geburtstag, edited by Joachim Gnika. Freiburg: Herder.

Barth, Karl. 1956. Church Dogmatics, IV. 1. Translated by G. W. Bromiley and T. F. Torrance. Edinburgh: T. and T. Clark.

Barth, Karl. 1961. Church Dogmatics I. 1. Translated by G. Bromiley. London: T. and T. Clark.

Bauman, Michael. 1987. Milton's Arianism. Bern: Peter Lang.

Behr, John. 2011. The Case against Diodore and Theodore. Oxford: Oxford University Press.

Bindley, T. Herbert. 1906. The Oecumenical Documents of the Faith. London: Methuen.

Bonner, H. B. 1934. Penalties upon Opinion. Edited by F. W. Read. London: Watts \& Co.

Bull, George. Works of George Bull. Vol II. Edited by Edward Burton. London: The University Press.

Calvin, John. 1989. The Institutes of the Christian Religion. Translated by Henri Beveridge. Grand Rapids: Eerdmans.

Chadwick, Henry. 1966. Early Christian Thought and the Classical Tradition. Oxford: Clarendon Press.

Clarke, Samuel. 1712. The Scripture Doctrine of the Trinity. London: James Knapton.

Cudworth, Ralph. 1820. Intellectual System of the Universe. Edited by Thomas Birch. London: Richard Priestley.

Dunn, James D. G. 1989. Christology in the Making. A New Testament Inquiry into the Origins of the Doctrine of the Incarnation, $2^{\text {nd }}$ edition. London: SCM Press.

Edwards, Mark. 2009. Catholicity and Heresy in the Early Church. London and New York: Routledge.

Eunomius. 1983. Liber Apologeticus. In Eunomius, The Extant Works, edited by Rrichard Paul Vaggione. Oxford: Clarendon Press.

Gioia, Luigi. 2008. The Theological Epistemology of Augustine's De Trinitate. Oxford: Oxford University

Press. https://doi.org/10.1093/acprof:oso/9780199553464.001.0001.

Hunter, William B. 1954. "Milton's Arianism Reconsidered?" Harvard Theological Review 52: 9-35. https://doi.org/10.1017/S0017816000026638. 
Hurtado, Larry. 2005. Lord Jesus Christ: Devotion to Jesus in Earliest Christianity. London: Bloomsbury.

Kelly, J. N. D. 1964. The Athanasian Creed. London: A. \& C. Black.

Ludlow, Morwenna. 2007. Gregory of Nyssa, Ancient and (Post)modern. Oxford: Oxford University Press. https://doi.org/10.1093/acprof:oso/9780199280766.001.0001.

Marius Victorinus, 1976. Against the Arians. In Marii Victorini Africi Opera Theologica, edited by Albrecht Locher. Leipzig: Teubner.

McNeill, J. T. 1967. The History and Character of Calvinism. New York: Oxford University Press.

Milton, John. 1973. Christian Doctrine. In Complete Prose Works of John Milton, vol. VI, edited by Maurice Kelley and translated by John Carey. New Haven: Yale University Press.

Milton, John. 1982. Art of Logic. In Complete Prose Works of John Milton, vol. VIII, edited by Maurice Kelley and translated by John Carey. New Haven: Yale University Press.

Nuttall, A. D. 1998. The Alternative Trinity. Oxford: Oxford University Press. https://doi.org/10.1093/acprof:oso/9780198184621.001.0001.

Pamphilus of Caesarea. 2005. Apologia pro Origene. Translated by G. Rowekamp. Turnhout: Brepols.

Quantin, Jean-Louis. 2009. The Church of England and Christian Antiquity. Oxford: Oxford University Press.

Rahner, Karl. 1961. "Theos in the New Testament." In Theological Investigations, vol. I. London: Darton, Longman and Todd.

Rahner, Karl. 1967. Theological Investigations, vol. IV. Translated by Kevin Smyth. London: Darton, Longman and Todd.

Smith, Mark. S. 2018. The Idea of Nicaea in the early Church Councils, A.D. 431-451. Oxford: Oxford University Press. https://doi.org/10.1093/oso/9780198835271.001.0001.

Warfield, Benjamin B. 1956. Calvin and Augustine. Philadelphia: Presbyterian and Reformation Publishing Company.

Westcott, B. F. 1892. The Epistles of St John. London: Macmillan.

Wiles, Maurice. 1996. Archetypal Heresy. Arianism through the Centuries. Oxford: Oxford University Press.

Wong, Joseph H. P. 1984. Logos-Sophia in the Christology of Karl Rahner. Rome: Libreria Arteneo Salesiana.

Zizioulas, John. 1985. Being as Communion. New York: St Vladimir's Seminary Press.

Published Online: February 05, 2020 